THUFULI: Jurnal Pendidikan Islam Anak Usia Dini

Volume 3 Nomor 1 Tahun 2021

e-ISSN: $\underline{2685161 X}$

\title{
IMPLEMENTASI METODE HALAQAH DALAM MENANAMKAN KARAKTER RABBANI ANAK DI LEMBAGA PENDIDIKAN ISLAM
}

\author{
Siti Makhmudah \\ Sekolah Tinggi Agama Islam Miftahul Ula Nganjuk \\ e-mail: makhmudahsiti87@gmail.com
}

Diterima: 26 Maret 2021 I Direvisi: 11 Mei 2021 I Disetujui: 14 Mei 2021

(C)2021 Pendidikan Guru Raudhatul Atfhal Fakultas Agama Islam Universitas Islam Malang

\begin{abstract}
In the learning there are usually students who are already fluent in reading the Quran, there are students who are very smart or quickin accepting material delivered by the teacher, even memorizing the Knowledge Islamic Education subject matter, and instead there also students who already know the meaning of educational lessons the religion of islam that has been conveyed by the teacher. But the student has not been able to apply it in daily life such as not respecting parents, not respecting the teacher, even not wanting to practice religious teachings islam is like prayer and fasting. In order to instill religious character of children in schools need to be held effective and efficient learning. Role learning methods and deposits are very important because this method is right to develop extra practice of Islamic religious education. This research is aimed to describe how the teacher plants religious characters children at school, in the research method uses qualitative research. The results of this study are: (1) The implementation of memorization and deposit methods by the teacher in instilling religious character in students in the school is the 4545 student memorizing the material and its explanation such as verses of the holy Quran and its translation, students will deposit the memorization results tothe teacher with the target that has been specified in the learning plan. (2) Problems with the implementation of memorization methods and teacher deposits in instilling religious character in students in schools are: students have not been able to read Arabic script, students' abilities are still lacking, learning media are still minimal. (3) The teacher's solution in solving the problematic implementation of memorization and deposit methods for inclution of the religious character of student is: students attend extracurricular activies, student are given additional assignments, the teacher makes learning media.
\end{abstract}

This work is licensed under Creative Commons Attribution Non Commercial 4.0 International License Available online on: http://riset.unisma.ac.id/index.php/fai/index 
Kata kunci: Implementation Memorization and Deposit Methods, Religious Character, kindergarten

\section{A. Pendahuluan}

Pendidikan anak usia dini adalah pendidikan yang diberikan kepada anak usia di bawah tujuh tahun. Di Indonesia kategori anak usia dini adalah anak berusia 0 tahun hingga 6 tahun. Anak usia dini lahir ke dunia dengan membawa segenap potensi (kecerdasan) yang dianugerahkan Tuhan, namun potensi-potensi tersebut tidak akan berkembang dan muncul secara optimal pada diri anak jika tidak distimulasi sejak usia dini (Gardner, 1983).

Sudaryanti (2010) mengungkapkan anak usia dini merupakan masa keemasan (golden age) yang hanya terjadi satu kali dalam masa perkembangan kehidupan, sekaligus masa yang kritis bagi kehidupan anak. Penelitian menunjukkan bahwa sejak lahir anak memiliki 1000 milyar sel otak, sel ini harus dirangsang dan didayagunakan agar terus hidup dan berkembang dan jika tidak dirangsang, sel ini akan mengalami penerunan dan berdampak pada pengikisan segena potensi yang dimiliki anak. Hal ini sejalan dengan filosof Montessori yang menyatakan bahwa, masa kanak-kanak adalah masa peka dan otak menyerap, sehingga anak-anak sangat membutuhkan stimulus untuk perkembangannya (Montessori: 2013).

Anak usia dini memiliki sikap spontan, baik dalam melakukan aktivitas maupun saat berinteraksi dengan orang lain. Anak tidak bisa membedakan apakah perilaku yang ditunjukkan dapat diterima oleh orang lain atau tidak dapa diterima, jika orang dewasa (seperti: orang tua, guru) tidak menyampaikan atau memberitahukan kepada anak secara langsung tentangperilaku-perilaku yang diharapkan masyarakat, memberikan contoh kepada anak tentang sikap-sikap yang baik, dan membiasakan anak untuk bersikap baik dalam kehidupan sehari-hari di manapun anak berada, namun yang menjadi bahan pertimbangan dalam pembentukan sikap anak agar menjadi individu yang bersikap baik adalah anak usia dini belum mengetahui banyak hal tentang bagaimana harus berperiku yang dapat diterima oleh masyarakat. Oleh karena itu peran pendidikan dibutuhkan untuk membantu penanaman karakter pada anak sejak usia dini melalui pendidikan karakter.

Ainissyifa (2014) pendidikan karakter harus ditanamkan sejak anak masih kecil dan melalui proses yang disesuaikan dalam tahapan perkembangan anak. Hal ini menunjukkan bahwa dalam pembentukan karakter anak dibutuhkan kesabaran dan ketekunan para pendidiknya yang harus didukung dengan keseimbangan 
antara pendidikan orang tua di rumah dengan pendidikan di sekolah. Sahlan (2013), menyatakan bahwa tujuan pendidikan karakter merupakan arah dalam pelaksanaan pendidikan di sebuah lembaga. Pendidikan karakter sangat urgen dalam kehidupan manusia khususnya kader-kader muda penerus bangsa Indonesia yang sekarang ini ditempuh dengan dekadensi moral di berbagai lembaga, termasuk dalam dunia pendidikan.

Kata karakter sudah tidak asing bagi siapapun yang mendengarnya. Dalam kehidupan sehari-hari sangat sering disebut, baik ketika melihat seseorang berperilaku baik maupun berperilaku buruk. Sudaryanti (2012) dalam kamus besar bahasa Indonesia, "karakter" diartikan sebagai sifat-sifat kejiwaan, akhlak, atau budi pekerti. Karakter juga dapat diartikan sebagai tabiat, yaitu perangai atau perbuatan yang selalu di lakukan atau kebiasaan. Hal ini sejalan dengan Suyanto (2012), bahwa karakter diartikan sebagai nilai-nilai, sikap, dan perilaku yang dapat diterima oleh masyarakat luas, seperti etis, demokratis, hormat, bertanggung jawab, dapat dipercaya, adil dan fair, serta peduli, yang bersumber dari nilai-nilai kemasyarakatan, ideologinegara, dan kewarganegaraan, nilai-nilai budaya bangsa, agama, dan etnik yang diterima oleh masyarakat Indonesia secara luas sehingga tidak menimbulkan konflik.

Zuchdi (2015) juga menjelaskan bahwa secara praktis, pendidikan karakter adalah suatu sistem penanaman nilai-nilai perilaku (karakter) kepada warga sekolah yang meliputi komponen pengetahuan, kesadaran atau kemauan, dan tindakan untuk melaksanakan nilai-nilai tersebut, baik terhadap Tuhan Yang Maha Esa, diri sendiri, sesama, lingkungan, maupun kebangsaan, sehingga menjadi manusia paripurna. Oleh karena itu karakter sebagai nilai-nilai yang dapat diterima oleh masyarakat membutuhkan sistem penanaman agar melekat pada diri manusia sehingga dapat berperilaku terpuji.

Prasetyo (2011) menjelaskan bahwa ada dua faktor yang mempengaruhi pembantukan karakter, yaitu bawaan dari dalam diri anak dan pandangan anak terhadap dunia yang dimilikinya, seperti pengetahuan, pengalaman, prinsip-prinsip moral yang diterima, bimbingan, pengarahan dan interaksi (hubungan) orang tua anak. Proses pembentukan karakter diawali dengan kondisi pribadi ibu-ayah sebagai figur yang berpengaruh untuk menjadi panutan, keteladanan, dan diidolakan atau ditiru anak-anak. Sikap dan perilaku ibu-ayah sehari-hari merupakan pendidikan watak yang terjadi secara berkelanjutan, terus-menerus dalam perjalanan umur anak.

Sudaryanti (2012) pembentukan karakter (character building) dapat di lakukan melalui pendidikan budi pekerti yaitu melibatkan aspek pengetahuan (cognitif), perasaan (feeling), dan tindakan (action). Ulwan (dalam Atabik dan 
Burhanuddin, 2015: 282-290) mengemukakan lima metode pendidikan, yaitu: 1) pendidikan dengan keteladanan. Orang tua yang telah memberikan keteladanan yang baik kepada anak, tidak boleh merasa sudah menunaikan segala tanggung jawab pendidikan anaknya. Artinya keteladanan diberikan secara terus-menerus sehingga keteladanan tersebut dapat membentuk karakter anak. 2) Pendidikan dengan kebiasaan (pengulangan). Burhanuddin (2015: 286) dalam mendidik anak usia dini, seorang pendidik baik orang tua maupun guru, dapat meminta seorang anak kecil (anak usia dini) untuk mengulang apa yang telah dia dapatkan dari pendidik berupa praktik yang telah dilakukan bersama mereka sebelumnya. 3) Pendidikan dan nasihat. Pendidikan dan nasihat dapat diberikan melalui kegiatan bercerita. Atabik dan Burhanuddin (2015: 288) metode cerita (kisah) ini sangat efektif dalam mendidik anak usia dini, sebab mereka memiliki tingkat penasaran tinggi, sehingga ketika mereka mendengar sesuatu yang baru, maka mereka akan memperhatikan dengan seksama apa yang dikisahkan oleh pendidik, dalam hal ini guru atau orang tua. Di akhir cerita seorang pendidik dapat menunjukkan hikmah di balik kisah yang baru saja diceritakan. Sehingga sejak dini mereka telah mendapatkan nilai-nilai pendidikan. 4) Pendidikan dengan memberikan perhatian dan pengawasan. Ulwan (dalam Atabik dan Burhanuddin, 2010) perhatian kepada anak dan mengontrol yang dilakukan oleh pendidik adalah asas pendidikan yang utama. Jika melihat sesuatu yang baik, dihormati, maka sang anak terus didorong untuk melakukannya. Jika melihat sesuatu yang jahat, maka harus dicegah, diberi peringatan dan dijelaskan akibatnya.

Dari beberapa pendapat ahli di atas, maka dapat disimpulkan bahwa penanaman Pendidikan karakter sangat pernting, karena pembiasaan dapat dimulai dari dini, mengingat pendapat Montessori, bahwa masa kanak-kanak ini adalah periode otak menyerap. Maka dari itu, penanaman pembiasaan dari kecil sangat mungkin untuk dilakukan.

Anak usia 4-6 tahun sudah harus mengenal bagaimana memiliki kepribadian terpuji, seperti menghormati orang yang lebih tua, tidak berbohong, mematuhi kata guru, dan saling menyayangi antar teman, namun pada kenyataannya di RA Kartini, Hutan, Ketandan, Kabupaten Nganjuk masih banyak didapati anak yang kurang mampu memahami tentang karakter baik. Hal tersebut terlihat dari beberapa anak yang sering berkata kotor, suka menggangu teman, kurang suka apabila diajak guru untuk melakukan kegiatan keagamaan, seperti kegiatan sholat berjamaah dan rame sendiri ketika berdoa, kurang menghargai guru, dan tidak jujur. Ada banyak faktor yang mempengaruhi tumbuhnya karakter tersebut (Sjarkawi dalam chairilsyah, 2012) diantaranya adalah (1) faktor internal, yaitu faktor yang beasal dari dalam diri anak. Faktor ini biasanya merupakan pengaruh bawaan/ keturunan yang 
mendominasi kerakter anak yang didapat dari orang tua. Misal ayah seorang pemarah maka anakanya kemungkinan besar juga menjadi pemarah. (2) Faktor eksternal, yaitu pengaruh yang berasal dari luar diri anak. faktor ini biasanya datang dari lingkungan diama anak berada, bisa dari keluarga, masyarakat atau media yang dijumpainya, seperti televisi, handphone/ gadget yang sekarang sedang marak, dan media-media lainnya.

Mengingat pentingnya mengenalkan pendidikan karakter pada anak usia dini, maka untuk mengatasi hal tersebut kemudian dilakukan penerapan metode halaqoh dalam menanamkan karakter rabbani (ketuhanan) pada anak usia dini di RA Kartini, Hutan, Ketandan, Kabupaten Nganjuk. Alasan dipilihnya metode halaqoh ini adalah karena dengan metode halaqoh anak akan membiasakan perilaku taat pada guru, tertib pada aturan, terbiasa jujur melalui kegiatan sorogan ( setoran). Metode ini biasanya jarang diterapkan di lembaga pendidikan anak usia dini atau jarang ditemukan sebagai metode pembelajaran, karena mempertimbangkan usia anak yang masih dalam tahap bermain. Namun ternyata dengan penerapan metode halaqoh dalam menanamkan karakter rabbani dengan mencontoh pendidikan di pesantren yang juga menaungi kelompok anak PAUD, diharapkan dapat membantu anak dalam mengenal dan memahami karakter terpuji yang harus dimiliki oleh anak.

Metode halaqoh sendiri diartikan sebagai kegiatan berupa pengajian yang disebut dengan pengajian halaqoah atau pengajian kelompok, yang dalam sejarah pendidikan Islam pendidikan model halaqoh dimaknai sebagai proses belajar mengajar, dimana seorang guru duduk di lantai menyampaikan materi pelajaran dan ia dilingkari murid-muridnya. (Izzudin, 2012).

Pendidikan dengan metode halaqoh memiliki program yang berkelanjutan, sehingga memperoleh suatu inetraksi secara islami dan intensif, penanaman aqidah, merangsang aspek nilai agama dan moral (NAM), dan pematangan perilaku secara berkelanjutan. Dalam metode ini tidak hanya sekedar mengenalkan anak tentang mengenal huruf hijaiyyah, namun juga pendidikan agama yang dilakukan untuk membentuk karakter terpuji dengan cara menanamkan nilai-nilai islami. Bukan hanya itu dengan metode halaqoh anak dirangsang untuk bisa bekerja sama, memimpin dan dipimpin, disiplin terhadap aturan, menyampaikan ide, dan belajar berkomunikasi (Basir, 2015: 11).

Berdasarkan konteks penelitian di atas, penelitian ini bertujuan untuk mendeskripsikan tentang penerapan metode halaqoh dalam menanamkan karakter rabbani di lembaga pendidikan islam, yang dalam hal ini peneliti melakukan penelitian di RA Kartini, Hutan, Ketandan, Kabupaten Nganjuk. Diharapkan dengan adanya penelitian ini manfaat yang dapat diperoleh secara praktis yaitu:1) Sebagai 
bahan pertimbangan untuk mengembangkan ilmu pengetahuan yang berkaitan dengan anak usia dini khususnya dalam pendidikan karakter, 2) Dapat meningkatkan pengetahuan anak tentang karakter terpuji namun tetap dalam lingkup perkembangan sesuai usia anak, 3.Dapat digunakan sebagai acuan dalam peneliltian selanjutnya khususnya dalam mengembangkan inovasi pembelajaran, 4 . dapat digunakan sebagai bahan pembinaan dan supervisi bagi para guru untuk peningkatan mutu pendidikan anak usia dini.

\section{B. Metode}

Dalam penelitian peneliti menggunakan metode kualitatif. Menurut Moleong (2014), penelitian kualitatif adalah penelitian yang dimaksudkan untuk memahami fenomena tentang apa yang dialami oleh subjek penelitian misalnya perilaku, motivasi, tindakan, dll. Secara holistik dan dengan cara deskriptif dalam bentuk kata-kata dan bahasa, pada suatu konteks khusus yang alamiah dan dengan memanfaatkan berbagai metode ilmiah.

Metode ini peneliti ingin mendeskripsi penerapan metode halaqoh dalam menanamkan karakter rabbani pada anak di lembaga pendidikan islam, khususnya di lembaga RA Kartini, Hutan, Ketandan, Kabupaten Nganjuk secara menyeluruh, luas, dan mendalam, baik kegiatan guru dalam merencanakan pembelajaran, faktor penghambat dan pendukung, dan evaluasi pembelajaran. Teknik pengumpul data dalam penelitian ini adalah: (1) Teknik observasi langsung yang dilakukan terhadap obyek di tempat berlangsungnya peristiwa, sehingga observer ada di tempat yang sama dengan obyek yang diamati. Peneliti menggunakan bentuk observasi partisipan dengan alat pengumpul data berupa panduan observasi dan catatan lapangan. Teknik ini digunak untuk mengobservasi kemampuan guru dalam merencanakan pembelajaran, mengetahui faktor penghambat dan pendukung, dan evaluasi pembelajaran dari penerapan metode halaqoh dalam menenamkan karakter rabbani pada anak, (2) teknik wawancara. Wawancara dilakukan dengan bertatap muka secara langsung antara peneliti selaku pewawancara dan dua orang guru kelas B RA Kartini, Hutan, Ketandan, Kabupaten Nganjuk sebagai informan/narasumber. Peneliti juga mewawancarai kepala TK Permata Bunda dan tiga orang tua anak sebagai bahan tambahan informasi untuk memperkaya hasil penelitian, (3) Teknik dokumentasi, daiman data-data yang dikumpulkan dalam penelitian ini yaitu berupa arsip-arsip seperti Rencana Kegiatan Harian (RKH), fotofoto pada saat pembelajaran, dan seluruh data hasil dokumentasi dapat menunjang proses penelitian. 


\section{Hasil dan Pembahasan}

1. Penerapan Metode Halaqoh dalam menanamkan karakter Rabbani pada Anak di Lembaga Pendidikan Islam

Berdasarkan hasil wawancara bersama guru kelas dan kepala lembaga tentang penerapan metode halaqoh dalam menanamkan kararkter rabbani ini dapat disimpulkan bahwa metode ini dipilih dikarenakan metode halaqoh dianggap tepat untuk mengingatkan dan memberi pemahaman anak tentang berperilaku baik dan memiliki karakter terpuji. Seperti halnya yang dilakukan di taman Pendidikan Al-Qur'an (TPQ) metode halaqoh juga cocok untuk diterapkan pada pendidikan anak usia dini, namun dengan tetap menyesuaikan usia anak dan sesuai indikator capaian perkembangan anak. Metode ini juga dilakukan dengan cara yang menyenangkan atau dengan bermain, seperti tebak huruf hijaiyyah, mengahafal surat-surat pendek, atau melalui berkisah islami.

Melalui metode halaqoh, banyak anak yang awalnya sering mengganggu anak lain, secara perlahan mulai dapat memahami artinya bertoleransi kepada temannya, dari yang suka berbohong sudah memahami sebab dan akibat dari tindakan tersebut, dari yang tidak paham tentang aturan berdoa, berubah menjadi lebih disiplin meskipun dengan karakteristik masing-masing anak, dari yang awalnya kurang bisa berbisa berbicara santun, sedikit demi sedikit belajar sopan dan menghormati guru.

Penerapan metode ini tentunya berjalan dengan beberapa tahapan, diantaranya adalah penyusunan Rencana Kegiatan Harian (RKH), yaitu menyiapkan media yang akan digunakan, seperti kartu huruf, buku cerita islami, dan juga Juz 30 (surat-surat pendek), menyediakan tempat untuk pelaksanaan metode halaqoh.

2. Faktor Penghambat dan Pendukung penerapan metode Halaqoh dalam Menanamkan Karakter Rabbani pada Anak di Lembaga Pendidikan Islam

Berdasarkan hasil observasi dan dokumentasi yang dilakukan peneliti ketika pembelajaran, faktor yang menjadi penghambat penerapan metode halaqoh adalah (1) ketertarikan anak, dimana ketika pelaksanaan duduk melingkar, masih banyak anak yng kurang merespon dan masih asik bermain, ada yang masih suka mengganggu teman dan bicara sendiri, sehingga tidak mendengarkan materi yang diberikan, (2) dukungan orang tua di rumah, yaitu banyak orang tua yang memberikan contoh negatif terhadap anak, seperti berkata kotor, pemarah, berbohong, kurang menghormati orang lain, sehingga anak yang berada dalam lingkungan yang tidak kondusif tersebut cenderung meniru dan guru harus lebih 
banyak mengulang materi yang diberikan hanya untuk sekedar mengingatkan anak.

Sedangkan untuk faktor pendukung penerapan metode halaqoh dalam menenamkan karakter rabbani adalah (1) sarana dan prasarana yang lebih memadai sehingga guru dapat lebih leluasa untuk mengaplikasikan metode halaqoh terhadap anak, (2) kreatifitas guru yang sangat menunjang penerapan metode halaqoh, yakni dengan pengetahuan islami dengan dikombinasikan keterampilan yang dimiliki akan mengahsilkan pembelajaran yang menyenangkan dan tidak membosankan, sehingga anak secara pasti dapat memahami tentang karakter rabbani dan cara berperilaku baik.

\section{Evaluasi Pembelajaran dari Penerapan Metode Halaqoh dalam Menanamkan Karakter Rabbani pada Anak di Lembaga Pendidikan Islam}

Dari pelaksanaan kegiatan pembelajaran, menurut guru kelas sudah pasti dilakukan evaluasi dan penilaian, yang diberikan pada setiap anak kelompok B, mulai dari awal kegiatan hingga sesi tanya jawab. Melalui evaluasi guru dapat mengurangi dan menambahkan hal yang kurang dalam penerapan metode halaqoh. Guru juga dapat menyiapkan alat dan bahan yang akan digunakan dalam penerapan selanjutnya. Misal, jika penerapan sebelumnya anak kurang berkosentrasi karena suara guru terlalu pelan, maka untuk penerapan selanjutnya guru dapat menyediakan alat pengeras suara, pada sesi sebelumnya guru sudah mejelaskan tentang materi menghormati orang yang lebih tua, maka selanjutnya guru bisa mengganti materi tentang berkata jujur, dan evaluasi lain yang menunjang pelaksanaan kegiatan metode halaqoh.

Dari hal tersebut di atas, maka dapat disimpulkan bahwa metode halaqoh berhasil menanamkan karakter baik pada anak, karena segala sesuatunya berjalan berurutan mulai awal hingga akhir seperti, mudahnya guru mengawasi anak, anak-anak merasa dianggap penting karena semua duduk di depan, namun metode ini dikatakan belum berhasil karena konsentrasi anak hanya bertahan 3 sampai 20 menit, sedangkan metode ini adalah teacher center, padahal pembelajaran yang baik adalah student center. Metode ini dapat dilakukan pada saat pembukaan pembelajaran, yang di dalamnya terdapat apersepsi dan diskusi singkat tentang materi yang akan disampai nanti.

Penanaman sikap baik dapat disampaikan pada saat apersepsi atau recalling saat pulang sekolah, karena anak-anak dalam keadaan tenang, sehingga dapat menyerapa dengan sempurna apa yang disampaikan guru. (Rani et al., 2015). 


\section{Simpulan}

Pendidikan anak usia dini merupakan pendidikan yang diberikan pada anak di bawah suia tujuh tahun. Pada usia dini merupakan usia dasar bagi orang tua dalam menanamkan karakter pada anak. Metode halaqoh menjadi pilihan RA Kartini, Hutan, Ketandan, Kabupaten Nganjuk untuk menanamkan karakater rabbani pada anak, dimana metode halaqoh adalah pembelajaran yang dilakukan secara melingkar dan guru berada ditengah-tengah anak untuk memberikan materi. Penerapan metode halaqoh yang ada di RA Kartini, Hutan, Ketandan, Kabupaten Nganjuk dilakukan diawali dengan penyusunan RKH (Rencana Kegiatan Harian), menyiapkan media pembelajaran, serta temat yang akan digunakan. Faktor pengahmbat dari penerapan metode halaqoh adalah ketertarikan anak dan dukungan orang tua, sedangkan faktor pendukung adalah sarana dan prasaran, serta kreatifitas guru.

\section{Daftar Rujukan}

Ainissyifa, H. 2014. Pendidikan Karakter dalam Perspektif Pendidikan Islam. Jurnal Pendidikan Universitas Garut Fakultas Pendidikan Islam dan Keguruan, Vol. 08 N0. 01 Hal. 1-26 ISSN 1907-932X.

Asmaun Sahlan. (2013). Pendidikan Karakter dalam Perspektif Islam (Kajian Penerapan Pendidikan Karakter di Lembaga Pendidikan Islam). Jurnal elHikmah Fakultas Tarbiyah UIN Malang hal. 139-149.

Atabik, A. \& Burhanuddin, A. (2015). Konsep Nasih Ulwan Tentang Pendidikan Anak. Elementary Vol. 3 No. 2 Juli-Desember 2015.

Basir, Yusuf. (2015). Pendidikan Karakter dengan Metode Halaqoh di Organisasi Masyarakat Wahdah Islamiyah Kota Yogyakarta. Yogyakarta. Skripsi UIN Sunan Kalijaga

Gardner, H. (1983). H owar d Frames of Mind.

Izzudin, M.A. (2012). Tradisi Akademik Pesantren Studi Tentang Pembelajaran Halaqoh di Ma'had Al-Hasyim Asy'ary Tebuireng. Surabaya. Tesis program pascasarjana UIN Sunan Ampel

Moleong, Lexy J. 2014. Metodologi penelitian Kualitatif. Bandung: PT. Remaja Rosdakarya

Montesori, Maria. Tanpa Tahun. Metode Montesori. Terjemah Gutex, Gerald Lee. 2013. Yogyakarta: Pustaka Pelajar.

Prasetyo, N. (2011). Seri Bacaan Orang Tua: Membangun Karakter Anak Usia Dini. Direktorat Pembinaan Pendidikan Anak Usia Dini.

Rani, A. M., CLONINGER, C. R., Saputro, B., \& Yogyakarta, U. M. (2015). Gaya

Kepemimpinan Bacharuddin Jusuf Habibie Pasca Orde Baru Tahun 1998-

1999. In American Journal of Psychiatry (Vol. 162, Nomor 4).

https://doi.org/10.1176/appi.ajp.162.4.820-a

Sudaryanti. (2010). Pentingnya Pendidikan Karakter Sejak Usia Dini Dalam 
Mewujudkan Warga Negara yang Baik. Makalah Dipresentasikan dalam Pengabdian Masyarakat yang Diselenggrakan Oleh Persekutuan Doa Keluarga Besar Kristen di Kadisoka, Purwomartani, Kalasan, Sleman. Jurnal Golden Age Universitas Hamzanwadi Vol. 01 No. 2, Desember 2017, Hal.82-89 E-ISSN : 2549-7367

Sudaryanti. (2012). Pentingnya Pendidikan Karakter Bagi Anak Usia Dini. Jurnal Pendidikan Anak, Volume 1, Edisi 1 Juni 2012.

Suyanto, S. (2012). Pendidikan Karakter untuk Anak Usia Dini. Jurnal Pendidikan Anak, Volume 1, Edisi 1 Juni 2012.

Zuchdi, D. dkk. (2015). Pendidikan Karakter Konsep Dasar dan Implementasi di Perguruan Tinggi. Yogyakarta: UNY Press. 